\title{
INFLUENCE OF PLANTING METHODS ON ROOT DEVELOPMENT, CROP PRODUCTIVITY AND WATER USE EFFICIENCY IN MAIZE HYBRIDS
}

\author{
Muhammad B. Khan ${ }^{1}$, Farhan Yousaf ${ }^{1}$, Mubshar Hussain ${ }^{1,2}$, Muhammad W. Haq ${ }^{1}$, Dong-J. Lee², \\ and Muhammad Farooq ${ }^{3 *}$
}

Optimum planting methods better ensure water and nutrient supply through improved root development resulting in better crop growth and productivity. This study was conducted to evaluate the effects of planting methods on root development, crop allometry, water use efficiency (WUE), productivity and economic returns of different maize (Zea mays L.) hybrids. Maize hybrids NK-6621, Pioneer-30Y87, and Pioneer-30Y58 were sown on beds, ridges, and flat surface. Ridge sowing was better followed by bed sowing; while amongst the hybrids, 'Pioneer-30Y87' performed the best. Well-developed root system, with longer primary root, more number of lateral roots and higher root growth rate, was observed in 'Pioneer30 Y87' planted on ridges, which led to higher WUE, grain yield and its related traits. The same hybrid exhibited higher leaf area index and crop growth rate, and maximum net return and benefit:cost ratio sowed on ridges. Overall, the ridge sowing improved root development resulting in better allometry, productivity $\left(5.45 \mathrm{t} \mathrm{ha}^{-1}\right)$, and WUE $\left(1.345 \mathrm{~kg} \mathrm{~m}^{-3}\right)$, in all the maize hybrids. Although maize hybrids exhibited different response to different planting methods; maximum grain yield (5.63 $\mathrm{t}$ $\left.\mathrm{ha}^{-1}\right)$, WUE $\left(1.41 \mathrm{~kg} \mathrm{~m}^{-3}\right)$, and net economic returns were observed from hybrid Pioneer-30Y87.

Key words: Allometry, planting methods, root growth rate, water use efficiency.

$\mathrm{W}$ ell developed root system with sufficient root elongation is imperative for better plant growth particularly with limited water and nutrient supply; whereas roots elongate with slower rate due to water stress and mechanical impedance in dry soils (Bengough et al., 2011). Limited moisture, hypoxia or anoxia, and mechanical impedance or compactions are the main reasons of poorly developed root system. Amid them, mechanical soil impedance play a major role to limit root growth even in soil as wet as $-100 \mathrm{kPa}$ with higher effective stress between soil particles due to tension created in water films between soil particles (Whalley et al., 2005). The problem is further aggravated with increased soil compaction due to heavy farm machinery used in arable systems; thus mechanical impedance becomes more important in limiting root growth than water stress (Bengough et al., 2006). More bulk density or dense surface soil layer is a limiting factor for root growth resulting in shorter root length and concentrate the roots near soil surface. Thus plants are forced to extract water and nutrients from limited soil volume (Chassot

${ }^{1}$ Bahauddin Zakariya University, College of Agriculture, Multan, Pakistan.

${ }^{2}$ Dankook University, Department of Crop Science and Biotechnology, Chungnam 330-714, Korea.

${ }^{3}$ University of Agriculture, Department of Agronomy, Faisalabad 38040, Pakistan. "Corresponding author (farooqcp@gmail.com).

Received: 1 March 2012.

Accepted: 13 July 2012. and Richner, 2002). Nonetheless, compacted soils are more vulnerable to water logging due to heavy rains and results in hypoxia limiting root growth (da Silva et al., 1994). Mechanical impedance reduced leaf expansion in hard soils due to direct signaling between root and shoot growth (Masle and Passioura, 1987; Young et al., 1997). But in case of ridges or raised bed, soil being loose and more or less weed free creates a better environment for aeration, light penetration, water movement, and root development (Roth et al., 2005; Khan et al., 2012).

Level of soil compaction, bulk density, and moisture condition are important factors influencing seedling emergence and final crop yield (Memon et al., 2007). Tillage practices to craft seedbed cause soil compaction and disturb balance between air and water components of soil and also increase the soil strength to restrict root growth; although a little compaction is also required for better contact of seed with soil particles (Memon et al., 2007). Well developed root systems with the ability to explore greater soil volume has been recognized as an important adaptation of plants to ensure sufficient water and nutrient uptake (Horst et al., 2001). In this regard, improved sowing methods like ridges and raised beds play a significant role to enhance crop productivity due to well developed root system. Ridges provide loose fertile layer of soil that result in well developed root system and consequently higher nutrient and water uptake (Khan et al., 2012). Recently, Bakht et al. (2011) reported better yield and related traits in ridge planted maize due to 
improved soil conditions for better root development, which helped in acquiring sufficient water and nutrients for plant growth and development.

Furthermore, improved sowing methods not only help to maintain optimum plant population with better emergence; but also enable plants to utilize land, light, and other input resources uniformly and efficiently. It is thus imperative to develop and optimize the planting method and geometry for avoiding excessive crowding and thereby enabling the plants to utilize these resources more effectively and efficiently (Quanqi et al., 2008). Likewise, now a day, success of modern agriculture depends on the ample supply of irrigation water either from canals or tube well sources but unfortunately continuous supply of quality irrigation water has become a challenge and now the world is focusing on water-wise cultivation (Deng et al., 2006). Water wise cultivation focuses on enhancing water-use efficiency (WUE) by harvesting higher economic yields on farmlands irrigated with minimum water (Ali and Ehsanullah, 2007; Farooq et al., 2009). Maximizing WUE is a valuable tool to economize the full use of natural precipitations and proficient management of irrigation network by adopting a suitable planting method (Hussain et al., 2010). Different planting methods not only improve water application efficiency, but they can also enhance the WUE. For instance, Abdullah et al. (2008) reported that ridge planting appreciably increased yield of maize and WUE compared with other planting methods.

Being polymorphic due to its cross pollinated nature, different maize hybrids behave differently to uptake water and nutrients from the soil due to their genetic makeup and rooting systems that largely depends on the soil and other environmental conditions. Hybrids with thicker roots pierce hard soil layers more efficiently and better maintain their root elongation rate in hard soils (Materechera et al., 1991; 1992). There are significant differences in DM production and nutrient uptake among maize genotypes (Akram et al., 2010). Different genotypes perform differently owing to their time to maturity and yield, which were the most important factors that influence maize yield (Maina et al., 2006).

Many researchers studied the performance of different maize genotypes under different planting methods and concluded that maize planted on ridges and raised beds performed well regarding growth and final yield of maize (Bakht et al., 2006; Abdullah et al., 2008; Bakht et al., 2011); but little information is available about the development of root system of maize hybrids under different planting methods. It was hypothesized that ridge sown maize perform better and produce higher grain yield owing to well-developed root system with higher root length and more root proliferation. This study was conducted to evaluate root development, crop productivity, and WUE of different maize hybrids sown by different planting methods.

\section{MATERIALS AND METHODS}

The present experiment was carried out at Agronomic Research Area, Department of Agronomy, Bahauddin Zakariya University, Multan $\left(71.43^{\circ} \mathrm{E}, 30.2^{\circ} \mathrm{N}, 122 \mathrm{~m}\right.$ a.s.1.), Pakistan, during autumn 2010. The climate of the region is subtropical to semi-arid. The experimental soil was sandy clay loam $(67.2,17.2$ and $15.6 \%$ sand, silt and clay contents) with $\mathrm{pH} 7.8$, EC $1.39 \mathrm{dS} \mathrm{m}^{-1}$, and $0.5 \%$ organic matter content.

The experiment was laid out according to randomized complete block design (RCBD) with split plot arrangements having a net plot size of $4 \mathrm{~m} \times 3 \mathrm{~m}$ and replicated four times. Planting methods and maize hybrids were randonized in main plots and sub plots, respectively. Three maize hybrids viz. NK-6621, Pioneer-30Y87, and Pioneer-30Y58, were sown on flat surface, ridges, and beds by keeping row to row distance of $75 \mathrm{~cm}$ and plant to plant distance of $20 \mathrm{~cm}$. During the experimental period, mean monthly temperature ranged from 26.45 to 32.80 ${ }^{\circ} \mathrm{C}$, relative humidity from 58.15 to $69.70 \%$; whereas a total of $317 \mathrm{~mm}$ rainfall was received.

\section{Crop husbandry}

Before crafting seedbed, pre-soaking irrigation of $10 \mathrm{~cm}$ depth was applied. When soil reached to workable moisture level, the seedbed was crafted by cultivating the field for two times with tractor-mounted cultivator each followed by planking. Sowing was performed on 10 July 2010 on well prepared seed beds of three types viz. ridges, beds, and flat seedbed. Sowing was done by using dibbler on flat seed bed and manually on ridges and beds by keeping plant to plant distance of $20 \mathrm{~cm}$. Nitrogen and $\mathrm{P}$ were applied at 200 and $150 \mathrm{~kg} \mathrm{ha}^{-1}$, respectively, using urea and diammonium phosphate (DAP) as a source. Full dose of $\mathrm{P}$ and half dose of $\mathrm{N}$ were applied at sowing, while second half dose of $\mathrm{N}$ was applied at knee height stage. After first irrigation, when soil reached to workable moisture level, hoeing was done to keep crop free from weeds. Crop was affected by shoot fly (Atherigona soccata) attack after 21 $\mathrm{d}$ after sowing (DAS). Furadan (carbofuran: 2,3-dihydro2,2-dimethylbenzofuran-7-yl methylcarbamate) was applied for the control of shoot fly (Atherigona soccata) using three grains $(1 \mathrm{~g})$ of insecticide per head from the top of the plant. All other agronomic practices were kept normal and uniform to keep crop free from insects and diseases. Mature crop was harvested on 29 October 2010.

Total number of plants in each plot at harvest was counted to record plant population. Plant height was recorded at maturity from 10 randomly selected plants with measuring tape and then averaged. Number of cobs of 10 randomly selected plants was counted and averaged to record number of cobs per plant. Cob length, number of rows per cob, and number of grains per cob were recorded from 10 randomly selected cobs from each plot and then averaged. Five random samples, each of 1000 
grains, were taken from seed lot of each plot, weighed and then averaged to compute 1000-grain weight. After harvesting the plants at maturity, cobs were separated, sun dried, manually threshed and grain yield per plot was recorded and converted into $\mathrm{kg} \mathrm{ha}^{-1}$ by unitary method and then adjusted to $10 \%$ moisture contents. To record biological yield, weight of air-dried plants (except cobs) was computed on net plot basis and then converted into $\mathrm{kg} \mathrm{ha}^{-1}$ and then recorded weight was added to the already calculated grain yield $\left(\mathrm{kg} \mathrm{ha}^{-1}\right)$ to obtain the biological yield. Harvest index (HI) was calculated as ratio between grain yield and biological yield expressed in percentage.

Water use efficiency (WUE) $\left(\mathrm{kg} \mathrm{m}^{-3}\right)$ was computed as (Viets, 1962):

\section{WUE $=$ Grain yield/Water applied}

where grain yield was expressed in $\mathrm{kg} \mathrm{m}^{-2}$ and water used was expressed in $\mathrm{mm}$ (irrigation applied + rainfall during the whole crop growth period).

Five plants at random were selected from each plot fortnightly to compute primary root length, number of lateral roots per plant, and root growth rate (RGR). The sampling started 30 DAS and terminated at harvest. Plants were uprooted with intensive care to evade root damage, washed thoroughly with water and air dried. Length of primary root was taken with the help of measuring tape and then averaged. Total number of lateral roots of all five plants were counted and averaged. Root growth rate (RGR) was computed following Hunt (1978).

Leaf area was recorded fortnightly by leaf area meter (DT Area Meter, Model MK2, Delta T Devices, Cambridge, UK) and leaf area index (LAI) was calculated following Watson (1947). Crop growth rate (CGR) was calculated following the procedures described by Hunt (1978). This sampling was also started 30 DAS and terminated at harvest.

\section{Statistical and economic analysis}

The collected data were statistically analyzed by using Fisher's ANOVA technique and least significant difference (LSD) test at 5\% probability level was used to compare differences among treatment means (Steel et al., 1997). Graphical data presentation was done using Microsoft Excel.

Economic and benefit-cost analysis was conducted to estimate the economic feasibility of growing maize hybrids by different sowing. The production costs of maize included field preparation, seed, sowing, fertilizing, weeding, crop protection measures, and harvesting. The gross income was estimated using the prevailing average market price of maize in Pakistan. Net income was calculated by subtracting total expenditure from the gross income while benefit:cost ratio (BCR) was computed by dividing the gross income with total expenditure.

\section{RESULTS AND DISCUSSION}

Sowing methods had significant effect on plant population, number of grains per cob, and 1000-grain weight while the effect was non-significant for cob length, number of cobs per plant, and number of rows per cob of maize (Table 1). Maize sown on ridges resulted in more plant population and 1000-grain weight while maize sown on beds exhibited higher number of grains per cob compared with the crop sown on flat surface (Table 1). There was significant difference amongst maize hybrids for plant population, cob length, number of grains per cob, and 1000-grain weight, there was no difference for number of cobs per plant and number of rows per cob (Table 1). Amongst hybrids, maximum plant population, number of cobs, number of grains per cob, and 1000-grain weight were observed in 'Pioneer-30Y87'; whereas minimum

Table 1. Influence of different planting methods on plant population and yield components of different maize hybrids.

\begin{tabular}{|c|c|c|c|c|c|c|}
\hline Treatments & $\begin{array}{c}\text { Plant } \\
\text { population per plot }\end{array}$ & $\begin{array}{l}\text { Cob } \\
\text { length }\end{array}$ & $\begin{array}{l}\text { Cobs } \\
\text { per plant }\end{array}$ & $\begin{array}{l}\text { Grain rows } \\
\text { per cob }\end{array}$ & $\begin{array}{l}\text { Grains } \\
\text { per cob }\end{array}$ & $\begin{array}{l}\text { 1000-grain } \\
\text { weight }\end{array}$ \\
\hline & & $\mathrm{cm}$ & & & & $\mathrm{g}$ \\
\hline \multicolumn{7}{|l|}{ Planting methods $(\mathrm{P})$} \\
\hline $\mathrm{P}_{1}=$ Flat sowing & $44.60 \mathrm{~b}$ & 16.94 & 1.03 & 14.83 & $431.83 b$ & $287.16 b$ \\
\hline $\mathrm{P}_{2}=$ Ridge sowing & $48.17 \mathrm{a}$ & 17.74 & 1.09 & 15.08 & $439.00 \mathrm{~b}$ & $310.41 \mathrm{a}$ \\
\hline $\mathrm{P}_{3}=$ Bed sowing & $45.50 \mathrm{~b}$ & 17.38 & 1.12 & 14.50 & $448.67 \mathrm{a}$ & $300.00 \mathrm{ab}$ \\
\hline LSD at p 0.05 & 1.37 & NS & NS & NS & 7.69 & 14.58 \\
\hline \multicolumn{7}{|l|}{ Maize hybrids (H) } \\
\hline $\mathrm{H}_{1}=\mathrm{NK}-6621$ & $43.83 b$ & $16.558 \mathrm{~b}$ & 1.06 & 14.66 & $424.67 \mathrm{c}$ & $282.33 b$ \\
\hline $\mathrm{H}_{2}=$ Pioneer-30Y87 & $47.83 \mathrm{a}$ & $18.158 \mathrm{a}$ & 1.06 & 15.16 & $453.25 \mathrm{a}$ & $324.08 \mathrm{a}$ \\
\hline $\mathrm{H}_{3}=$ Pioneer-30Y58 & $46.68 \mathrm{a}$ & $17.344 \mathrm{ab}$ & 1.13 & 14.58 & $441.58 b$ & $291.16 b$ \\
\hline LSD at p 0.05 & 1.84 & 0.831 & NS & NS & 10.16 & 15.51 \\
\hline \multicolumn{7}{|l|}{ Interaction $\mathrm{P} \times \mathrm{H}$} \\
\hline $\mathrm{P}_{1} \mathrm{H}_{1}$ & $44.25 \mathrm{c}$ & 16.30 & 1.00 & $15.00 \mathrm{ab}$ & $428.50 \mathrm{~d}$ & $276.50 \mathrm{~d}$ \\
\hline $\mathrm{P}_{1} \mathrm{H}_{2}$ & $43.50 \mathrm{c}$ & 16.22 & 1.10 & $14.25 \mathrm{bc}$ & $427.00 \mathrm{~d}$ & $303.00 \mathrm{bc}$ \\
\hline $\mathrm{P}_{1} \mathrm{H}_{3}$ & $43.75 \mathrm{c}$ & 17.15 & 1.08 & $14.75 \mathrm{ab}$ & $418.50 \mathrm{~d}$ & $267.50 \mathrm{~d}$ \\
\hline $\mathrm{P}_{2} \mathrm{H}_{1}$ & $45.25 \mathrm{c}$ & 17.47 & 1.08 & $15.00 \mathrm{ab}$ & $445.25 \mathrm{c}$ & $303.00 \mathrm{bc}$ \\
\hline $\mathrm{P}_{2} \mathrm{H}_{2}$ & $50.00 \mathrm{ab}$ & 19.15 & 1.10 & $15.50 \mathrm{a}$ & $462.50 \mathrm{ab}$ & $341.25 \mathrm{a}$ \\
\hline $\mathrm{P}_{2} \mathrm{H}_{3}$ & $48.25 b$ & 17.85 & 1.00 & $15.00 \mathrm{ab}$ & $452.00 \mathrm{bc}$ & $328.00 \mathrm{ab}$ \\
\hline $\mathrm{P}_{3} \mathrm{H}_{1}$ & $44.50 \mathrm{c}$ & 17.05 & 1.03 & $14.50 \mathrm{bc}$ & $421.75 d$ & $282.00 \mathrm{~cd}$ \\
\hline $\mathrm{P}_{3} \mathrm{H}_{2}$ & $51.00 \mathrm{a}$ & 17.85 & 1.08 & $15.50 \mathrm{a}$ & $427.50 \mathrm{~d}$ & $287.00 \mathrm{~cd}$ \\
\hline $\mathrm{P}_{3} \mathrm{H}_{3}$ & $44.50 \mathrm{c}$ & 17.12 & 1.28 & $13.75 \mathrm{c}$ & $475.50 \mathrm{a}$ & $304.50 \mathrm{bc}$ \\
\hline LSD at p 0.05 & 2.37 & NS & NS & 0.95 & 13.33 & 25.25 \\
\hline
\end{tabular}

Means sharing the same letters in a column do not differ at $\mathrm{p}=0.05$; LSD: least significant difference; NS: Non significant. 
plant population, smaller cobs and lesser number of grains per cob of small size were recorded in 'NK-6621' (Table 1). Interaction between sowing methods and maize hybrids had significant effect on plant population, number of grains per cob and 1000-grain weight while the interaction was non-significant for cob length, number of cobs per plant, and number of rows per cob of maize (Table 1). 'Pioneer-30Y87' exhibited maximum plant population on ridges and beds while all maize hybrids exhibited minimum plant population on flat surface (Table 1). Maximum number of grains per cob were recorded when hybrids Pioneer-30Y87 and Pioneer30 Y58 were sown on ridges and beds, respectively (Table 1). Likewise, higher 1000-grain weight was recorded in maize hybrids Pioneer-30Y87 and Pioneer-30Y58 sown on ridges (Table 1).

Different planting methods had significant effect on plant height, grain and biological yield and WUE; however the effect was non-significant for HI (Table 2). Maximum plant height, grain and biological yields and WUE were observed in ridge sown maize while crop sown on flat surface performed feebly (Table 2). Maize hybrids differed significantly for grain and biological yield and WUE; however, the difference was nonsignificant for plant height and HI (Table 2). Maximum grain and biological yield and WUE were obtained in 'Pioneer-30Y87' whereas minimum grain and biological yield and WUE were recorded in 'NK-6621' (Table 2). In case of interaction between sowing methods and hybrids, both 'Pioneer-30Y87' and 'NK-6621' attained more plant height when sown on ridges (Table 2). Similarly, maximum biological yield was observed in 'Pioneer-30Y58' sown on ridges and the minimum in the same hybrid sown on

Table 2. Influence of different planting methods on plant height, crop productivity, harvest index and water use efficiency (WUE) of different maize hybrids.

\begin{tabular}{|c|c|c|c|c|c|}
\hline Treatments & $\begin{array}{l}\text { Plant } \\
\text { height }\end{array}$ & $\begin{array}{l}\text { Grain } \\
\text { yield }\end{array}$ & $\begin{array}{l}\text { Biological } \\
\text { yield }\end{array}$ & $\begin{array}{l}\text { Harvest } \\
\text { index }\end{array}$ & WUE \\
\hline & $\mathrm{cm}$ & - & $\mathrm{ha}^{-1}$ & $\%$ & $\mathrm{~kg} \mathrm{~m}^{-3}$ \\
\hline \multicolumn{6}{|l|}{ Planting methods $(\mathrm{P})$} \\
\hline $\mathrm{P}_{1}=$ Flat sowing & $193.69 b$ & $4.86 \mathrm{c}$ & $25.79 \mathrm{c}$ & 18.81 & $1.22 \mathrm{c}$ \\
\hline $\mathrm{P}_{2}=$ Ridge sowing & $201.66 a$ & $5.45 \mathrm{a}$ & $30.01 \mathrm{a}$ & 18.24 & $1.34 \mathrm{a}$ \\
\hline $\mathrm{P}_{3}=$ Bed sowing & $198.94 \mathrm{ab}$ & $5.13 b$ & $28.51 b$ & 18.35 & $1.28 \mathrm{~b}$ \\
\hline LSD at $p 0.05$ & 6.77 & 0.19 & 0.78 & NS & 0.05 \\
\hline \multicolumn{6}{|l|}{ Maize hybrids $(\mathrm{H})$} \\
\hline $\mathrm{H}_{1}=\mathrm{NK}-6621$ & 195.22 & $4.63 c$ & $26.48 \mathrm{c}$ & 17.86 & $1.16 \mathrm{c}$ \\
\hline $\mathrm{H}_{2}=$ Pioneer $-30 \mathrm{Y} 87$ & 202.04 & $5.63 \mathrm{a}$ & $30.18 \mathrm{a}$ & 18.97 & $1.41 \mathrm{a}$ \\
\hline $\mathrm{H}_{3}=$ Pioneer $-30 \mathrm{Y} 58$ & 197.03 & $5.14 b$ & $27.65 b$ & 18.57 & $1.29 \mathrm{~b}$ \\
\hline LSD at $p 0.05$ & NS & 0.24 & 0.98 & NS & 0.06 \\
\hline \multicolumn{6}{|l|}{ Interaction $\mathrm{P} \times \mathrm{H}$} \\
\hline $\mathrm{P}_{1} \mathrm{H}_{1}$ & $185.83 \mathrm{~d}$ & $4.51 \mathrm{e}$ & $25.13 d$ & 17.96 & $1.13 \mathrm{e}$ \\
\hline $\mathrm{P}_{1} \mathrm{H}_{2}$ & $199.43 b$ & $4.50 \mathrm{e}$ & $31.33 b$ & 14.36 & $1.13 \mathrm{e}$ \\
\hline $\mathrm{P}_{1} \mathrm{H}_{3}$ & $200.40 \mathrm{ab}$ & $4.87 \mathrm{~d}$ & $22.99 \mathrm{e}$ & 21.26 & $1.22 \mathrm{~d}$ \\
\hline $\mathrm{P}_{2} \mathrm{H}_{1}$ & $202.10 \mathrm{ab}$ & $5.58 b$ & $26.47 d$ & 21.11 & $1.40 \mathrm{~b}$ \\
\hline $\mathrm{P}_{2} \mathrm{H}_{2}$ & $205.80 \mathrm{a}$ & $6.13 a$ & $30.66 \mathrm{~b}$ & 20.01 & $1.53 \mathrm{a}$ \\
\hline $\mathrm{P}_{2} \mathrm{H}_{3}$ & $198.23 b c$ & $5.20 \mathrm{c}$ & $33.41 \mathrm{a}$ & 15.78 & $1.30 \mathrm{c}$ \\
\hline $\mathrm{P}_{3} \mathrm{H}_{1}$ & $193.163 \mathrm{c}$ & $4.48 \mathrm{e}$ & $25.78 d$ & 17.36 & $1.12 \mathrm{e}$ \\
\hline $\mathrm{P}_{3} \mathrm{H}_{2}$ & $199.75 b$ & $5.71 b$ & $28.06 \mathrm{c}$ & 20.35 & $1.43 \mathrm{~b}$ \\
\hline $\mathrm{P}_{3} \mathrm{H}_{3}$ & $198.20 b c$ & $5.24 \mathrm{c}$ & $29.12 \mathrm{c}$ & 18.01 & $1.31 \mathrm{c}$ \\
\hline LSD at $p 0.05$ & 5.84 & 0.33 & 1.34 & 1.55 & 0.08 \\
\hline
\end{tabular}

Means sharing the same letters in a column do not differ at $\mathrm{p}=0.05$; LSD: least significant difference; NS: Non significant. flat surface (Table 2). Nonetheless, maximum grain yield and WUE were harvested from 'Pioneer-30Y87' sown on ridges (Table 2).

Length of primary root and number of lateral roots per plant progressively increased with increasing growth period (Figures 1 and 2). All the tested maize hybrids observed sizeable improvement in primary root length sown on ridges followed by bed sowing, although the response of hybrids was different. 'Pioneer-30Y87' sown on ridges while 'NK-6621' and 'Pioneer-30Y58' sown both on ridges and beds observed higher primary root length than the crop sown on flat surface through the entire growth period (Figure 1). Maize hybrid NK6621 observed same pattern of root proliferation under all sowing methods except 45 DAS, while 'Pioneer30Y87' and 'Pioneer-30Y58' observed considerably higher root proliferation under ridge sowing up to 60 DAS and under ridge and bed sowing at 75 DAS compared with the crop sown on flat surface (Figure 2). The RGR progressively increased up to 60 DAS and then start declining (Figure 3). Sowing methods had non-significant effect on RGR of 'NK-6621' during entire growth period, while ridge sowing significantly improved RGR of 'Pioneer-30Y87' and 'Pioneer30 Y58' at 60 and 75 DAS but it was at par with bed sowing in case of 'Pioneer-30Y87' (Figure 3). Overall

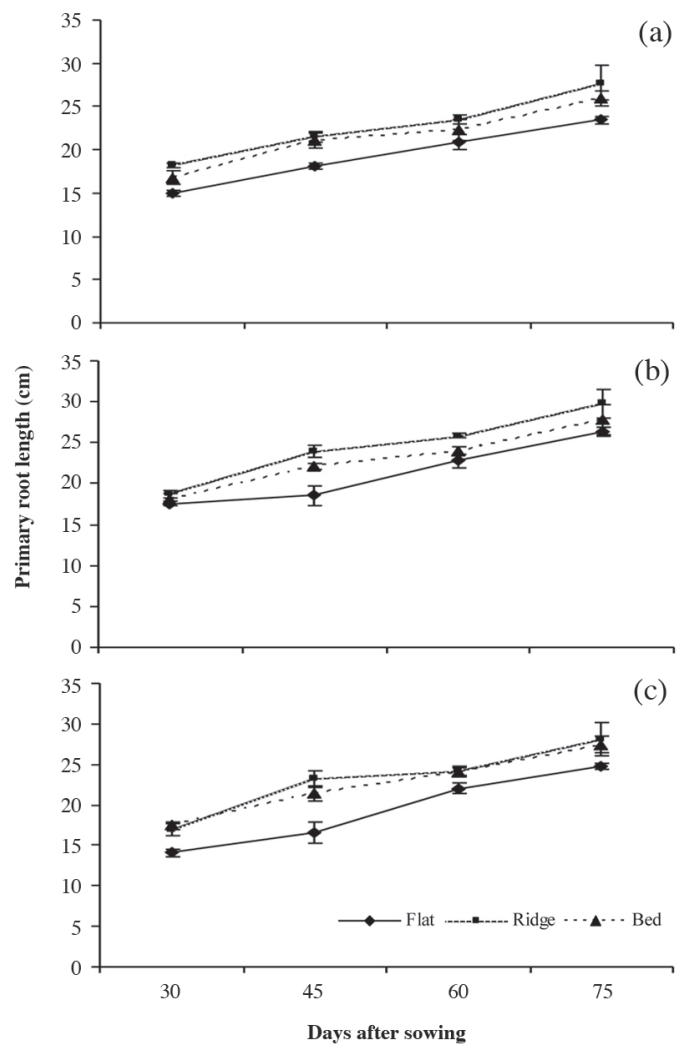

Figure 1. Influence of planting methods on primary root length of maize hybrids (a) NK-6621, (b) P-30Y87, and (c) P-30Y58. 

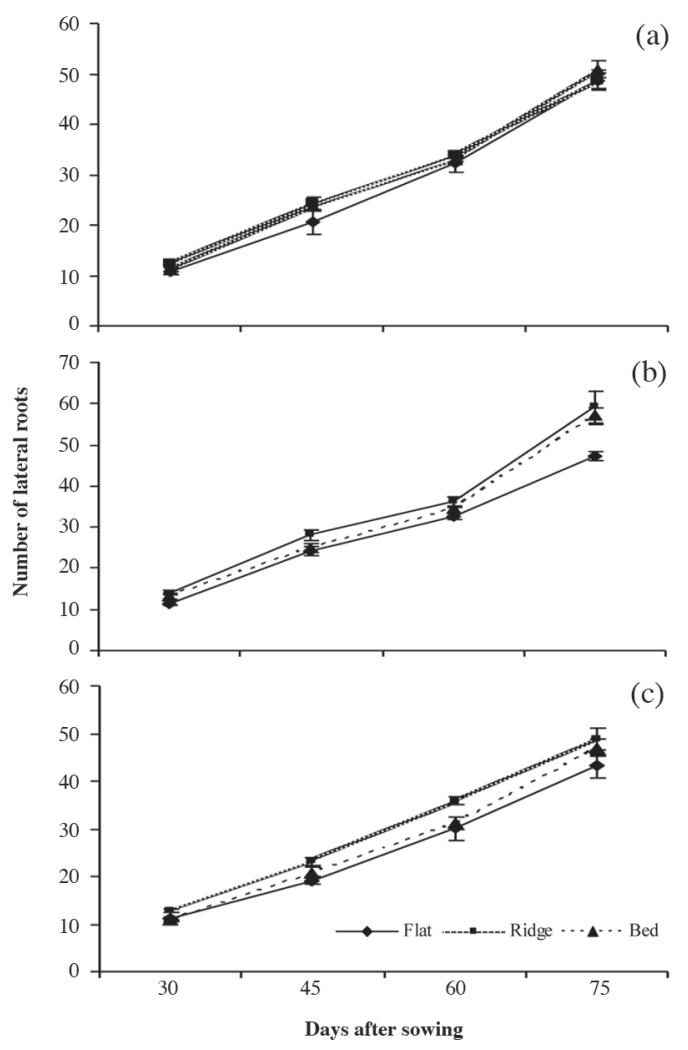

Figure 2. Influence of planting methods on number of lateral roots of maize hybrids (a) NK-6621, (b) P-30Y87, and (c) P-30Y58.

'Pioneer-30Y87' observed higher root length, root proliferation and RGR than other hybrids under study especially under ridge sowing (Figures 1-3).

Leaf area index and crop growth rate (CGR) progressively increased up to 60 DAS and then start declining (Figures 4 and 5). At 60 and 75 DAS, ridge sown crop shaped maximum LAI and CGR in all tested maize hybrids in almost similar fashion followed by bed sowing compared with the crop sown on flat surface; whereas at 30 and 45 DAS, planting methods had non-significant effect on LAI and CGR (Figure 4 and 5). Moreover, 'Pioneer-30Y87' observed a bit higher LAI and CGR throughout the growing season than other hybrids tested (Figure 4 and 5).

Maize sown on ridges exhibited higher while sown on flat surface exhibited lower net income and benefit:cost ratio (BCR), respectively (Table 3). Among maize hybrids, Pioneer-30Y87 outperformed with higher net income and BCR whereas, NK-6621 exhibited minimum net income and BCR. With respect to interaction between planting methods and maize hybrids, Pioneer-30Y87 sown on ridges outperformed with higher net income and BCR while NK-6621 sown on beds and all hybrids sown on flat surface performed feebly with minimum economic returns and reduced BCR (Table 3 ).

Maximum grain yield, its related traits and WUE

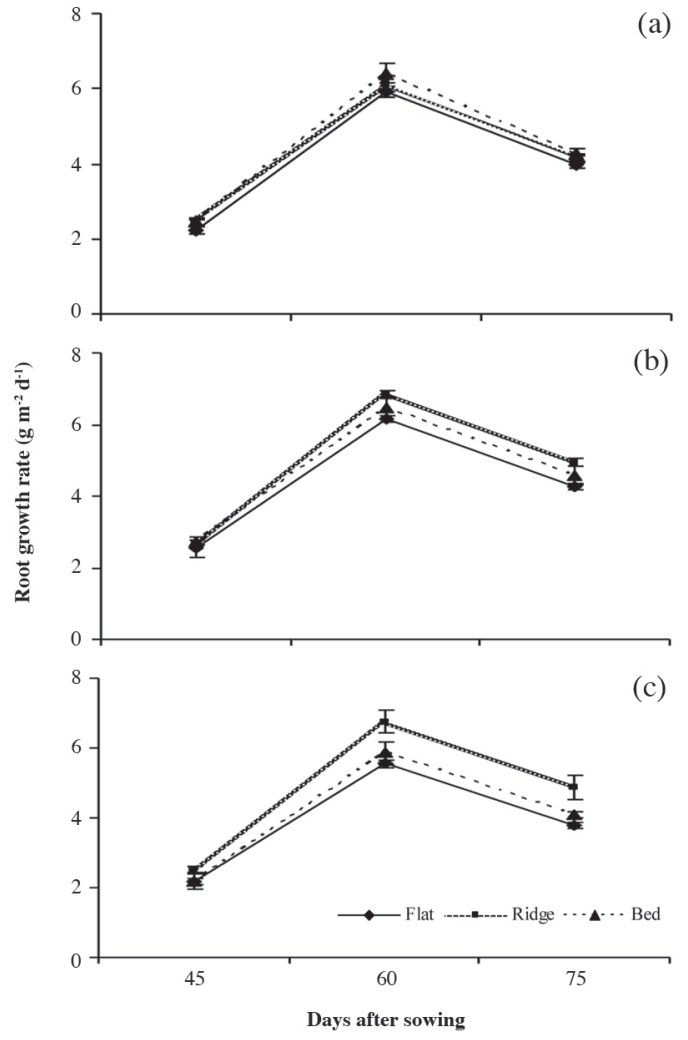

Figure 3. Influence of planting methods on root growth rate of maize hybrids (a) NK-6621, (b) P-30Y87, and (c) P-30Y58.

were observed in maize hybrids sown on ridges (Table 2) due to well developed root system (Figures 1-3). The well developed root system with long primary root and higher root proliferation might enhance water and nutrient uptake; resulting in better LAI (Figure 4), and CGR (Figure 5), leading to more bigger grains in cobs (Table 1).

Table 3. Influence of different planting methods on net income and benefit-cost ratio of different maize hybrids.

\begin{tabular}{lcccc}
\hline Treatments & $\begin{array}{c}\text { Total } \\
\text { expenditure }\end{array}$ & $\begin{array}{c}\text { Gross } \\
\text { income }\end{array}$ & $\begin{array}{c}\text { Net } \\
\text { income }\end{array}$ & $\begin{array}{c}\text { Benefit-cost } \\
\text { ratio }\end{array}$ \\
\cline { 2 - 3 } & \multicolumn{3}{c}{ Rs ha $^{-1}$} & \\
\cline { 2 - 3 } Sowing methods (P) & & & & \\
$\mathrm{P}_{1}=$ Flat sowing & 72425 & 115425 & 43000 & 1.59 \\
$\mathrm{P}_{2}=$ Ridge sowing & 74575 & 129438 & 54863 & 1.74 \\
$\mathrm{P}_{3}=$ Bed sowing & 74575 & 121838 & 47263 & 1.63 \\
Maize hybrids (H) & & & & \\
$\mathrm{H}_{1}=$ NK-6621 & 74575 & 109963 & 35388 & 1.47 \\
$\mathrm{H}_{2}=$ Pioneer-30Y87 & 74575 & 133713 & 59138 & 1.79 \\
$\mathrm{H}_{3}=$ Pioneer-30Y58 & 74575 & 122075 & 47500 & 1.64 \\
$\mathrm{Interaction} \mathrm{P} \times \mathrm{H}_{\mathrm{P}_{1} \mathrm{H}_{1}}$ & 72425 & 107113 & 34688 & 1.48 \\
$\mathrm{P}_{1} \mathrm{H}_{2}$ & 72425 & 106875 & 34450 & 1.48 \\
$\mathrm{P}_{1} \mathrm{H}_{3}$ & 72425 & 115663 & 43238 & 1.60 \\
$\mathrm{P}_{2} \mathrm{H}_{1}$ & 74575 & 132525 & 57950 & 1.78 \\
$\mathrm{P}_{2} \mathrm{H}_{2}$ & 74575 & 145588 & 71013 & 1.95 \\
$\mathrm{P}_{2} \mathrm{H}_{3}$ & 74575 & 123500 & 48925 & 1.66 \\
$\mathrm{P}_{3} \mathrm{H}_{1}$ & 74575 & 107350 & 32775 & 1.44 \\
$\mathrm{P}_{3} \mathrm{H}_{2}$ & 74575 & 135613 & 61038 & 1.82 \\
$\mathrm{P}_{3} \mathrm{H}_{3}$ & 74575 & 124450 & 49875 & 1.67 \\
\hline 1 & & & & \\
\hline
\end{tabular}

1 US\$ $=93.76822$ Rs Pakistan. 
Ridges provide apposite soil conditions like proper aeration and adequate availability of moisture essential for emergence that resulted in more plant population compared with flat seed bed (Abdullah et al., 2008; Bakht et al., 2011). Likewise, ridges and beds provided loose fertile soil with more aeration and moisture availability, and less mechanical compaction that permitted roots to grow profusely with more length, better proliferation and root growth rate (Figures 1-3). Chassot and Richner (2002) reported that more bulk density or dense surface soil layer is a limiting factor for root growth resulting in less root length and concentrate the roots near soil surface. Better root system enhanced the water and nutrient uptake resulting in high LAI (Figure 4). LAI indicates the size of assimilatory system of crop, which captures solar radiation for $\mathrm{C}$ assimilation; higher LAI thus provide more area for photoassimilation resulting in higher CGR (Figure 5). Earlier, Rasheed et al. (2003) and Hussain et al. (2010) also quoted higher LAI and CGR in ridge sown maize (Zea mays L.) and sunflower (Helianthus annuus L.), respectively compared with the crop sown on flat surface. That bigger assimilatory system due to higher LAI and higher CGR resulted in more DM production, and plant height, number of grains per cob and 1000-grain weight (Tables 1 and 2).

Significant improvement in yield contributing factors
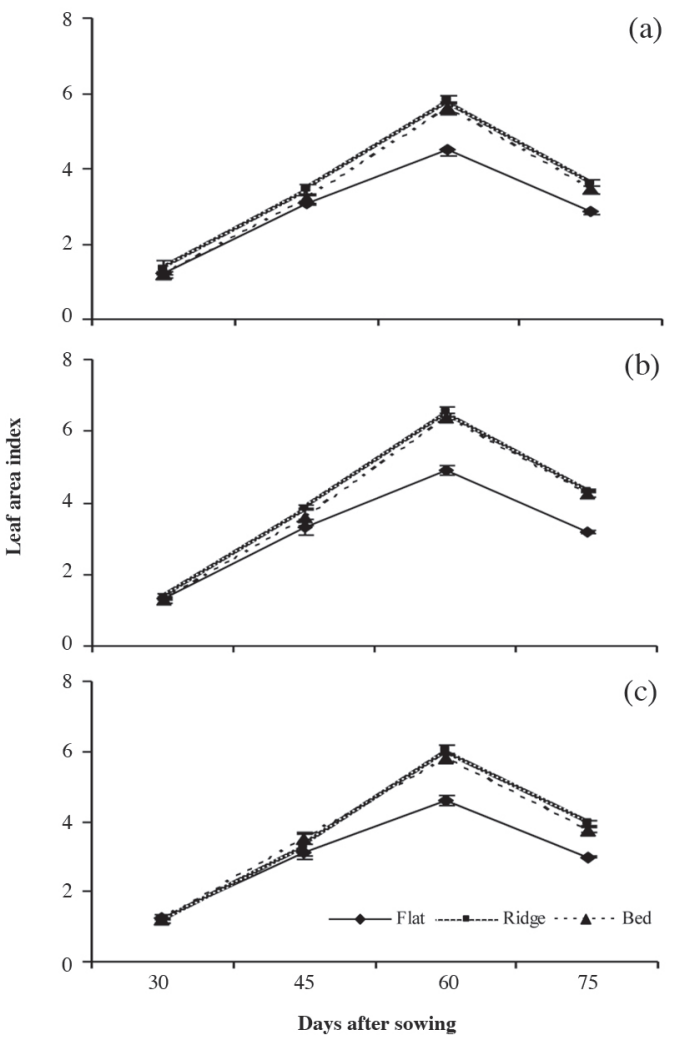

Figure 4. Influence of planting methods on leaf area index of maize hybrids (a) NK-6621, (b) P-30Y87, and (c) P-30Y58. contributed in harvesting better grain yield in ridge sown crop (Table 2). Apposite soil conditions crafted by ridges for proper root development that ensured efficient accessibility of water and nutrients for proper growth might be the reason of improved grain yield of maize. Likewise higher biological yield in ridge sown maize was the result of positive soil conditions crafted by ridges resulting into better root system; enabling the plants to uptake more moisture and nutrients to produce higher LAI that resulted higher CGR (Figures 4 and 5) and in consequence higher DM production. Increased WUE in ridge sown maize was direct result of grain yield improvement; as same amount of water was applied in all sowing methods.

Amid maize hybrids under study, 'Pioneer-30Y87' outperformed with higher grain yield and WUE due to significantly better yield related traits owing to its better genetic makeup. 'Pioneer-30Y87' produced better root system with longer primary roots, more root proliferation and higher root growth rate (Figures 1-3) that might be due to its better genetic makeup; as different maize hybrids behave differently due to their genetic makeup (Akram et al., 2010; Khan et al., 2012). Due to better root system, 'Pioneer-30Y87' got better access to water and nutrients helping in growth and higher LAI (Figure 4). Higher rate of DM production due to better CGR resulted in more plant

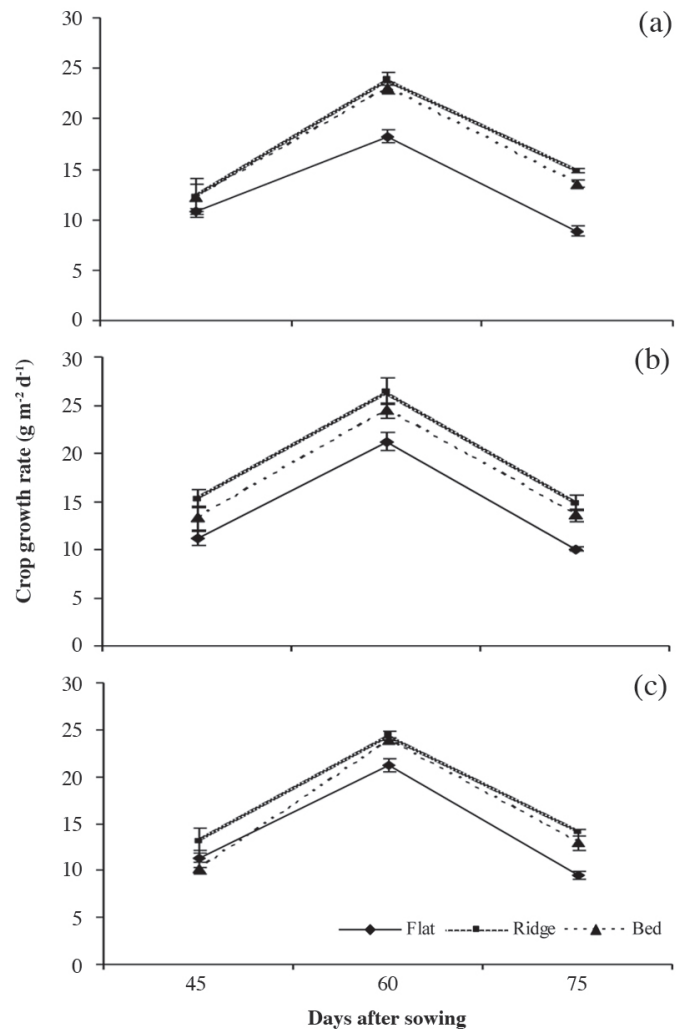

Figure 5. Influence of planting methods on crop growth rate of maize hybrids (a) NK-6621, (b) P-30Y87, and (c) P-30Y58. 
height, cob length, number of grains per cob and grain weight (Tables 1 and 2). Due to significant improvement in yield components and more DM production, higher grain and biological yield were harvested from hybrid 'Pioneer30Y87' (Table 2). Higher WUE in 'Pioneer-30Y87' was only due to its higher grain yield as same quantity of water was applied to all maize hybrids.

With respect to interactive effect of hybrids and sowing methods, 'Pioneer-30Y87' outperformed upon sowing on ridges with higher grain yield WUE (Table 2). Best performance of 'Pioneer-30Y87' on ridges was the pooled effect of better genetic makeup of hybrids and apposite conditions for growth created by ridges due to lose fertile soil with better aeration and moisture availability (Bakht et al., 2011; Khan et al., 2012). In consequence of that pooled effect, 'Pioneer-30Y87' sown on ridges attained better root system (Figures 1-3), higher LAI and CGR (Figures 4 and 5 ) and longer cobs with more gains of bigger size and ultimately higher grain and biological yield and WUE.

Higher net income and BCR exhibited by 'Pioneer30 Y87' sown on ridges was the direct result of enhanced grain productivity (Table 3) due to more efficient utilization of available resources due to well developed root system (Figures 1-3). Adoption of any technique ultimately depends on its economic feasibility and cost involved. Therefore, higher economic returns obtained by sowing of 'Pioneer-30Y87' sown on ridges highlight its economic feasibility and hence it may be practiced to harvest higher productivity.

\section{CONCLUSIONS}

Maize hybrid Pioneer-30Y87 exhibited maximum plant population, number of grains per cob, 1000-grain yield, grain and biological yield, primary root length, number of lateral roots, root growth rate, and water use efficiency when sown on ridges. Likewise, maximum economic returns with higher benefit:cost ratio were also obtained from the same hybrid planted on ridges. Ridge sowing may be therefore promoted for higher productivity and water use efficiency.

\footnotetext{
Influencia de métodos de siembra sobre el desarrollo radical, productividad y eficiencia del uso del agua en híbridos de maíz. Métodos óptimos de siembra aseguran mejor suministro de agua y nutrientes a través del mejorado desarrollo de raíces que resulta en mejor crecimiento y productividad de los cultivos. Este estudio se realizó para evaluar los efectos de los métodos de siembra en el desarrollo de las raíces, alometría de cultivos, uso eficiente del agua (WUE), productividad y rentabilidad económica de diferentes híbridos de maíz (Zea mays L.). Híbridos de maíz NK-6621, Pioneer 30Y87, y 30Y58-Pioneer se sembraron en camas, surcos, y superficie plana. La siembra en surco fue mejor, seguida por siembra en cama, mientras entre los
}

híbridos, 'Pioneer 30Y87' tuvo los mejores resultados. Se observó un sistema radical bien desarrollado, raíz primaria más larga, mayor número de raíces laterales, y mayor tasa de crecimiento radical, en 'Pioneer-30Y87' plantado en surcos, lo que condujo a mayores WUE, rendimiento de grano y sus rasgos relacionados. El mismo híbrido sembrado en surcos presentó mayores índice de área foliar y tasa de crecimiento del cultivo, máximo rendimiento neto y relación beneficio:costo. En general, la siembra en surco mejoró el desarrollo radical resultando en mejores alometría, productividad $(5,45$ t ha-1), y WUE $\left(1,35 \mathrm{~kg} \mathrm{~m}^{-3}\right)$, en todos los híbridos de maíz. Aunque los híbridos de maíz mostraron respuesta diferente a los diferentes métodos de siembra, máximos rendimientos de grano $\left(5,63 \mathrm{t} \mathrm{ha}^{-1}\right), \operatorname{WUE}\left(1,41 \mathrm{~kg} \mathrm{~m}^{-3}\right)$, y retornos económicos netos se observaron en el híbrido Pioneer 30 Y 87.

Palabras clave: alometría, métodos de siembra, tasa de crecimiento de raíces, uso eficiente del agua.

\section{LITERATURE CITED}

Abdullah, G.H., I.A. Khan, S.A. Khan, and H. Ali. 2008. Impact of planting methods and herbicides on weed biomass and some agronomic traits of maize. Pakistan Journal of Weed Science Research 14:121-130.

Akram, M., M.Y. Ashraf, E.A. Waraich, M. Hussain, N. Hussain, and A.R. Mallahi. 2010. Performance of autumn planted maize (Zea mays L.) hybrids at various nitrogen levels under salt affected soils. Soil and Environment 29:23-32.

Ali, L., and Ehsanullah. 2007. Water use efficiency of different planting methods in cotton (Gossypium hirsutum L.) Journal of Agricultural Research 45:299-304.

Bakht, J., S. Ahmad, M. Tariq, H. Akber, and M. Shafi. 2006. Response of maize to planting methods and fertilizer N. Journal of Agricultural and Biological Science 1:8-14.

Bakht, J., M. Shafi, H. Rehman, R. Uddin, and S. Anwar. 2011 Effect of planting methods on growth, phenology and yield of maize varieties. Pakistan Journal of Botany 43:1629-1633.

Bengough, A.G., M.F. Bransby, J. Hans, S.J. McKenna, T.J. Roberts, and T.A. Valentine. 2006. Root responses to soil physical conditions: growth dynamics from field to cell. Journal of Experimental Botany 57:437-447.

Bengough, A.G., B.M. McKenzie, P.D. Hallett, and T.A. Valentine. 2011. Root elongation, water stress, and mechanical impedance: a review of limiting stresses and beneficial root tip traits. Journal of Experimental Botany 62:59-68.

Chassot, A., and W. Richner. 2002. Root characteristics and phosphorus uptake of maize seedlings in a bilayered soil. Agronomy Journal 94:118-127.

da Silva, A.P., B.D. Kay, and E. Perfect. 1994. Characterization of the least limiting water range of soils. Soil Science Society of America Journal 58:1775-1781.

Deng, X.-P., L. Shan, H. Zhang, and N.C. Turner. 2006. Improving agricultural water use efficiency in Arid and Semiarid areas of China. Agricultural Water Management 80:23-40.

Farooq, M., N. Kobayashi, A. Wahid, O. Ito, and S.M.A. Basra. 2009. Strategies for producing more rice with less water. Advances in Agronomy 101:351-388.

Horst, W.J., M. Kamh, J.M. Jibrin, and V.O. Chude. 2001. Agronomic measures for increasing $\mathrm{P}$ availability to crops. Plant and Soil 237:211-223.

Hunt, R. 1978. Plant growth analysis. Studies in Biology $\mathrm{N}^{\circ}$ 96. p. 26-38. Edward Arnold, London, UK 
Hussain, M., M. Farooq, K. Jabran, and A. Wahid. 2010. Foliar application of glycinebetaine and salicylic acid improves growth, yield and water productivity of hybrid sunflower planted by different sowing methods. Journal of Agronomy and Crop Science 196:136-145

Khan, M.B., R. Rafiq, M. Hussain, M. Farooq, and K. Jabran. 2012. Ridge sowing improves root system, phosphorous uptake, growth and yield of maize (Zea mays L.) hybrids. Journal of Animal and Plant Sciences 22:309-317.

Maina, J., E. Nyamwaya, and E. Mukhwana. 2006. Strategies testing and promotion of new maize cultivars in western Kenya. Journal of Agronomy 17:154-159.

Masle, J., and J.B. Passioura. 1987. The effect of soil strength on the growth of young wheat plants. Australian Journal of Plant Physiology 14:643-656.

Materechera, S.A., A.M. Alston, J.M. Kirby, and A.R. Dexter. 1992. Influence of root diameter on the penetration of seminal roots into a compacted subsoil. Plant and Soil 144:297-303.

Materechera, S.A., A.R. Dexter, and A.M. Alston. 1991. Penetration of very strong soils by seedling roots of different plant-species. Plant and Soil 135:31-41.

Memon, S.Q., B.B. Mirza, and G.R. Mari. 2007. Tillage practices and effect of sowing methods on growth and yield of maize. Journal of Agriculture in the Tropics and Subtropics 40:89-100.

Quanqi, L., C.L. Yuhai, L. Mengyu, Z. Xunbo, D. Baodi, and Y. Songlie. 2008. Water potential characteristics and yield of summer maize in different planting patterns. Plant, Soil and Environment 54:14-19.
Rasheed, M., A. Hussain, and T. Mahmood. 2003. Growth analysis of hybrid maize as influenced by planting techniques and nutrient management. International Journal of Agriculture and Biology 5:169-171.

Roth, C.H., R.A. Fisher, and C.A. Meisner. 2005. Evaluation and performance of permanent raised bed cropping systems in Asia, Australia and Mexico. Proceedings of a workshop held in Griffith, Australia. 1-3 March 2005. ACIAR Proceedings N ${ }^{\circ} 121$. 63 p. Australian Centre for International Agricultural Research (ACIAR), Canberra, Australia.

Steel, R.G.D., J.H. Torrie, and D.A. Deekey. 1997. Principles and procedures of statistics: A biometrical approach. $3^{\text {rd }}$ ed. p. $400-$ 428. McGraw Hill Book, New York, USA.

Viets, F.G.J. 1962. Fertilizers and the efficient use of water. Advances in Agronomy 14:223-264.

Watson, D.J. 1947. Comparative physiological studies on the growth of field crops. I. Variation in net assimilation rate and leaf area between species and varieties, and within and between years. Annals of Botany 11:41-76.

Whalley, W.R., P.B. Leeds-Harrison, L.J. Clark, and D.J.G. Gowing. 2005. Use of effective stress to predict the penetrometer resistance of unsaturated agricultural soils. Soil and Tillage Research 84:1827.

Young, I.M., K. Montagu, J. Conroy, and A.G. Bengough. 1997. Mechanical impedance of root growth directly reduces leaf elongation rates of cereals. New Phytologist 135:613-619. 